\title{
The relevance of pedagogical narrative maps: The Confession of Belhar as a practical theological narrative searching for a pedagogic-therapeutic methodology.
}

\begin{abstract}
This article explores the pedagogic value of the Confession of Belhar within a practical theology narrative framework as a potential therapeutic practice for racial (pre- and post-1994) traumatic experiences. Recurring and hidden occurrences of oppression, injustice, inferiority and disunity engender psycho-social dysfunctionality in church and society (De Beer \& Van Niekerk 2009:50-52). The deconstruction of structuralist hegemonic paradigms will be undertaken. Secondly, a contextual analysis of liberating poststructuralist paradigm/s serves as foundation for the article. Thirdly, the appropriation of narrative pedagogical maps is explored. Fourthly, different narrative maps within a pedagogical framework are applied to illuminate two (Koopman 2008; Strauss 2005) opposing narratives. Finally, suggestions are provided of how narrative pedagogy could be applied to address pre- and post1994 conditions of oppression, injustice and disunity. The Confession is proposed as a narrative pedagogical model in addressing ecclesial and psycho-social dysfunctionalities. The objective is to explore how racial trauma and hegemonic conditions can be addressed and transformed into alternative living possibilities, respectively.
\end{abstract}

\section{INTRODUCTION}

Many South Africans and certain life conditions, it could be concurred, suffer from postapartheid hegemonic practices, trauma or stress and are in need of transformation and healing (Koopman 2008; Landman 2009; Van Rooi 2010). Racism feeds on hegemonic power, fosters and assumes cultural and logical inferiority (Koopman 2008:160). Koopman (2008:159) concur that his identity and humanity was deformed during the apartheid era through direct and indirect violence of racism. The Confession of Belhar (the Confession henceforth) with its formative and transformative nature embodies historical and contemporary suffering of marginalised communities (Dames 2009; De Beer \& Van Niekerk 2009; Koopman 2008). The current racial depiction (on the internet - "the Facebook Racist") and generational conflict in society highlights the dangers of racial fundamentalism and growing leadership intolerance (http:// www.timeslive.co.za/sundaytimes/?gclid=CKL-ys6r-aoCFdAJtAodKBIIIg; http://www.news24. com/Galleries/Image/Images/MyNews24/Malema\%20Luthuli\%20hearing). Young leaders in South Africa are in need of an appropriate historical framework. Members of society require conversations of remembrance and re-authoring if we are to treasure the 1994 democratic achievements of a new South Africa. Suffice it to argue that these conditions were fostered by the lack of addressing pre- and post-1994 hegemonic practices of apartheid through pedagogic and therapeutic interventions. The hidden powers or unintentional rationalisation of racism amongst Black, 'Coloured' and White communities complicate and even duplicate historical 
apartheid-like oppression, injustice and inferiority (Koopman 2008; Strauss 2005:563). A recent inappropriate argument about the Confession illuminates the potential re/production of pre1994 hegemonic and inferiority notions:

Therefore, a confession must correlate with the core issues of "God's revelation in Jesus

Christ" without entertaining "beuselagtighede" [nonsense] (Strauss 2005:563).

Strauss' (2005) reference to "beuselagtighede" or nonsense could be regarded as a paternalistic attempt to disregard the audience's authentic faith expression and values embodied in the Confession. It characterises 'White' supremacy enacted in the re/production of oppression, injustice and inferiority through hegemonic discourse (Van Dijk 1993). What or who defines the abovementioned "core issues of "God's revelation in Jesus Christ"? Strauss (2005:563) notion of "core issues" reminds of historic paternalistic discourse within DRC circles (Botha \& Naude 1998). Koopman's (2008:162) depiction of decades of insufferable suffering and the emergence of a new transforming story constitutes "the core issues of "God's revelation in Jesus Christ" for millions of Black, 'Coloured', Indian and White South Africans during and after apartheid. Bam (in Botha \& Naude 1998:34-37) declared a status confessionis on the basis of apartheid and apartheid theology's threat on the Gospel of Jesus Christ. Apartheid and apartheid theology engineered collective and structural contexts of violence through racial prejudice, separation, discrimination, exclusion, alienation, enmity, injustice, humiliation and dehumanization. It culminated in the Dutch Reformed Church's (DRC) racial based missionary policy and nationalist ("volksgesentreerde") ecclesiology (De Beer \& Van Niekerk 2009).

\section{STATUS CONFESSIONIS AS A PEDAGOGICAL TRANSFORMATION NARRATIVE}

A transformed narrative, however, dawned with the declaration of a status confessionis in 1982 and the adoption of the Confession in 1986 (Naude \& Botha 1998). It was this very same faith response of the Confession that sought consolation, comfort, redemption, liberation, hope and healing for all South Africans (Koopman 2008:162).

Koopman's notion of the Confession as the God-given event of consolation, liberation, hope, etcetera illuminates the confession's formative, transformative nature and therapeutic function. We concur that the Confession embodies both a therapeutic and pedagogical function in fostering unity, reconciliation and justice. The pre-1994 apartheid context was renowned for separation, discrimination, alienation, enmity, racism, injustice and oppression. The Confession redressed these ideological and structural hegemonies with liberational intent (cf. Botha \& Naude 1998). A new narrative or discourse on "solidarity and cohesion, embracing and participation, compassion and human rights" was introduced (Koopman 2008:162-164). This therapeutic narrative transformed structural injustice, separation and racism and engendered the formation of a new kind of citizenship and or Christianity (McLaren 2001). Particularly, in the light of Polany's (in McLaren 2001:151) notion of meaning formation for everything in life within its location/context in society.

The hypothesis of this article holds that hidden pre-1994 hegemonic practices continues to threaten the moral and spiritual fibre of churches and society; that it require a narrative pedagogical methodology in reaffirming our Christian and democratic ideals and values; and in fostering healing for psycho-social dysfunctionality in church and society.

\subsection{Defining narrative pedagogical methodology}

Goodson, Biesta, Tedder and Adair (2010:133) refer to unexplored and underdeveloped methodologies in engendering narrative learning; and calls for the exploration of new learning resources and new learning environments. This article seeks to address familiar, albeit critical 
issues within a new methodological framework. Narrative pedagogy reveals deeper perspectives of life, interprets and analyses data from reality in engendering social consciousness (Clough 2002:8). Postmodern conditions require methodological accountability for complex moral issues: "Self-reflexivity [within the written story] unmasks complex political/ideological agendas" (Richardson 1994:523 in Clough 2002:9).

Narrative pedagogy from faith traditions constitutes an important method in redressing old and in forming new worldviews (Ploeger 1995:275). Novelli (2008:6-8) in his book Shaped by the Story offers a new pedagogical framework based on the narrative methodology. Narratives are powerful in incorporating people into new spaces - it opens up new perspectives and places and introduces us to new people. Narratives illuminate and form personal and communal identity and character. Narratives are a dialogue-centred approach in forming new knowledge, values and praxis. Novelli (2008:7) argues that narratives are "guided by imaginative listening, creative retellings, and interactive discussions". It is an inspirational method for learners to discover themselves in sequences of events that include characters, dialogue, context, and plot. Narrative pedagogy engenders a revised perspective, reorganised and prioritised new style and mode of living. Suffice it to warn that we do not intent to disregard the conceptual, theoretical principles of the Confession of Belhar in favour for a mere imaginative methodological project (Murphy 2007:1). We contend with Novelli that [the Confession] as an embodied narrative is a pedagogy of formation and transformation - especially in the light of post-1994 communities confronted with psycho-social and socio-economic scars of apartheid. Narrative therapy is ideal in redressing tangible, hidden and silent re/occurrences of oppression, injustice, discrimination and isolation (Landman 2009; Freedman \& Combs 1996; Morgan 2000; White 2007).

Life stories are linked through certain events and in a particular sequence over time: "The key distinction that emerges is that between the use of life narratives as tools for learning, agency and identity construction and the ongoing process of narration itself as a site for learning" (Goodson et.al 2010:131). Plots are formed for dominant or alternative stories to inculcate and engender new meaning. "A narrative is like a thread that weaves ${ }^{1}$ the events together, forming a story" (Morgan 2000:5). Narrative therapy attends to the self and the Other regarding personal and communal life stories. We tell stories in order to make sense of ourselves and our circumstances (Winslade \& Monk 1998:1). Narrative pedagogy is a respectful, non-blaming approach that centres people as the experts of their own lives. People possess various skills, competences, beliefs, values, commitments and abilities. These traits could help them to change their relationship towards injustice, inequality and hegemony. Narrative pedagogy is determined by people or communities in terms of their own outcomes (Morgan 2000:4).

\subsection{Narrative pedagogical therapy and social construction}

The narrative metaphor represents a discontinuous paradigm within hegemonic structuralist social and institutional contexts. This paradigm shift is also referred to as "post-structuralism, deconstructionism, the interpretive turn, new hermeneutics, and postmodernism" (Freedom \& Combs 1996:14).

Structuralism and or objective study methods were developed to analyse the laws/structures in life and things to provide supposedly reliable, valid and universally applicable knowledge of the physical world (Thomas 2002:85). This objective worldview emphasises facts, replicable procedures, and rules. It, however "ignores the specific, localized meanings of individual people" (Freedman \& Combs 1996:9; Thomas 2002:85) (own accentuation). We contend that the uniqueness of the former Dutch Reformed Mission Church (DRMC hereafter) and the Uniting

1 See also the book A Chorus of Voices. Weaving Life's Narratives in Therapy and Training (Kotze 2000).

The relevance of pedagogical narrative maps 27 
Reformed Church in South Africa's (URCSA ${ }^{2}$ henceforth) members were and are still being disregarded by some white supremacy practices (Strauss 2005:563,572-575). Structuralism implies that people are studied, perceived and treated objectively in posing paternalistic pedagogical guidance and therapy (Koopman 2008:161; Strauss 2005; Thomas 2002:86).

Today post-structuralism or postmodernity is challenging the abovementioned assumptions of structuralism. The French philosophers, Michel Foucalt ${ }^{3}$ and Jacques Derrida ${ }^{4}$, are the founding fathers of post-structuralism. They influenced disciplines in which hegemonic objective/ structuralistic methodologies are applied (Thomas 2002:86).

Social realities, the taken for granted conditions in life (injustice, etcetera), are constructed by the members of a particular culture through reciprocal relationships. Social construction provides individuals and communities with hegemonic or liberating frameworks through which they interpret their world. We contend that the Confession, as theological and social construction, functioned as a liberating and pedagogical therapeutic framework during the pre-1994 period it reconfigured the lives and word views of DRMC/URCSA members (De Beer \& Van Niekerk 2009; cf. Freedman \& Combs 1996:12; Hartney 2011; Koopman 2008:162). Narrative pedagogy, within a postmodern and social constructionist worldview deconstructs power, knowledge and truth and, informs how it works in diverse communities and cultures (Freedman \& Combs 1996:22). The Confession, for instance, as a deconstruction of hegemonic structuralist and objective worldviews; reframed the aforementioned realities into post-structuralist, intersubjective, postmodern life-giving world views (Koopman 2008:162; Hartney 2011; Ploeger 1995).

\subsection{The transformation of structuralist practices}

The Confession transformed the structuralist philosophy, identity and culture of apartheid ideology and its theological justification. The Confession embodies Christ's creativity, transformation, social cohesion, compassion, reconciliation, love, hope and peace (Koopman 2008:166; cf. Louw 2008). The Confession assisted the former structuralist DRMC to decentre itself, and to embrace a new identity with an alternative narrative (Koopman 2008:162-166). The following perspectives of Thomas (2002:88) underlines the pedagogical contribution of the Confession in terms of alternative possibilities (cf. De Beer \& Van Niekerk 2009:54-58), namely: (1) identities are not fixed, but in a constant process of being created; (2) identity is being created in relationship to changes to which others are reacting and witnessing; (3) identities are socially (by history, culture, gender, sexuality, class and power relations) created; (4) people's identities cannot be known by the truths of scientific methods; (5) therapists do not posses objective, neutral or value-free understandings, and should not impose their perspectives on

2 References to both the former Dutch Reformed Mission Church and the new Uniting Reformed Church in South Africa are used to describe its rich historical and contemporary narratives. The DRMC was founded on racially segregated grounds - the URCSA was formed as a decentred ecclesial denomination between the Dutch Reformed Church in Africa and the DRMC (reserved for Black and 'Coloured' people, respectively). The Dutch Reformed Church (henceforth DRC - for White people) previously referred to itself as the 'Mother' of the aforementioned 'daughter' churches. The DRC was the brain child of the apartheid ideology/narrative.

3 Foucalt's (in Morkel 2008) contribution should be noted. He focuses on language as an instrument of power; distinguishes between the tension of normal/abnormal, power/resistance, life giving/life taking; dominant narratives as units of power and meaning; truth claims which constitute discourses that dehumanize and objectify people.

4 Derrida (in Morkel 2008) is also essential in this regard. He argues for the following: the meaning of any symbol, word or text inextricably bound up in its context; deconstruction of structuralist's meaning systems; the absent but implicit in meaning; taking a term under erasure, to undo not to destroy; and the binary opposition of: not either/or but both/and possibilities in meaning. 
others; and (6) the (un-harmful) quirks of people's lives (times, places, events, ways of being that do not fit the normal) and its formative meaning in people's lives. To concur with Thomas, the Confession therefore shaped the lives and conditions of the marginalised majorities in our country through existential, social and communal identity formation and transformation. The Confession remains appropriate in the reconfiguration of dysfunctional identities (xenophobia, homosexuality, HIV and AIDS) and hegemonic discourses (Dames 2009; De Beer \& Van Niekerk 2009; Koopman 2008).

\subsection{New possibilities for co-existence and co-operation}

Post-structuralism is capable of opening up new possibilities for creative forms of listening to and working with [URCSA and DRC] people (De Beer \& Van Niekerk 2009:58; Thomas 2002:88). Theological deconstruction through the Confession demonstrates the value of a poststructuralist pedagogical methodology (Koopman 2008:162-164). It illustrates how theological transformation as well as deformation could exist between two identical, but different confessional narrative versions (Koopman 2008; Strauss 2005). Albeit, from the same confessional tradition, the traditional confessions (Strauss 2005) and the new status of confessionis (Koopman 2008). The essence of the comparison between the two narratives is that the confessions' traditional confessional text did not change. The way the traditional and new confessionis' narratives were read reflects how the DRC audience have objectified the Confession as a political discourse or just as a piece ("stuk") or "document" (De Beer \& Van Niekerk 2009:63; Strauss 2005). Members of the DRMC embraced it as an intersubjective (liberation, communal) life-giving praxis (Hartney 2011; Koopman 2008). The setting in which the Confession and the traditional confessions' narrative functioned changed, but not the traditional confessional textual intent. The new status of confessionis demonstrated that a poststructuralist culture is essential for a transformed worldview. Traditional confessions were projected by the DRC as a preferred culture of structuralism, certainty and normativity - it was claimed as the product of a preferred paternalistic institutionalised community (Strauss 2005:560-572; cf. Taylor 2005:19-29). The Confession represents a changed worldview, a postmodern culture in which narrative pedagogical therapy has a distinctive function. It provides a new vision and therapy for audiences through their local and particular social and cultural poststructuralist contexts (cf. De Beer \& Van Niekerk 2009:58,63). A break between the way things used to be and the way it is today, was realised. De Beer and Van Niekerk (2009) presume to capture the Confession for the DRC's ecclesiological and missionary legitimacy; instead of embracing it as a liberating witness in confessing the atrocities of apartheid and the theological justification of apartheid. The pre-1994 context of the Confession provides us with a good example of how a therapeutic pedagogical community (DRMC/URCSA) engaged in and through mutual formative and transformative opportunities with its fellow members and the public.

We will consequently apply the Confession as a therapeutic narrative pedagogical methodology within a growing poststructuralist context.

\section{DEFINING NARRATIVE MAPS}

White (2007:5-6) holds that maps for therapeutic practice should serve as a critical reflective guide in the development of therapeutic conversations. Maps as a metaphor could inform narrative pedagogy in addressing existential psycho-social concerns, dilemmas and problems of communities. Narrative therapy within a pedagogical perspective could empower communities to reconfigure their goals or to embrace new objectives to transform their lives (cf. White 2007:4). Partnerships for transformation result in the acknowledgement and embracing of 
diverse cultural relationships (White 2007:5; Ploeger 1995). Maps engender opportunities for people to explore neglected life events and existential psychosocial problems. It fosters constructive and creative engagement with oppressive, unjust and existential problems (White 2007:5). Narrative pedagogical therapy maps can be constructed in terms of White's (2007) narrative frameworks, namely: externalizing; re-authoring; re-membering; unique outcomes; and scaffolding conversations. White's framework is ideal in addressing pre- and post 1994 hegemonic conditions by helping suffering communities to externalise, re-author and remember the past in recreating a new hopeful future through scaffolding conversations of unity, reconciliation and justice as unique outcomes.

\subsection{Externalizing conversations identifying the thin descriptions in narrative pedagogy} White (2007:9) proposes the externalizing conversations map as an antidote (not as a skill/ technique) to psychological self understandings. Externalizing conversations detached the person/community from their problem or suffering (injustice, separation and inferiority). It deconstructs practices of injustice, discrimination and the objectification of people or organisations as inferior. The collective existential experience of the DRMC during the 1980's characterised such practices and perceptions (Koopman 2008:159-162; cf. White 2007:9; Freedman \& Combs 1996:47). Narrative pedagogy should help oppressed people or communities to separate their personalities, identities and culture from hegemonic conditions (White 2007:9; Morgan 2000:17). In the context of externalizing conversations, inferiority ceases to represent the truth about people's identities (White 2007:9). Narrative pedagogy assists people in naming their problems (plots of suffering, inferiority, injustice and separation) in search of tangible problem resolution (Koopman 2008:159-162; Morgan 2000:17; White 2007:9). ${ }^{5}$ This is realised through the Confession as an example of creative and authentic linguistics with a therapeutic narrative pedagogical intent and orientation. The Confession, however, was initially and may still be perceived as a "mistaken problem-identity" of the former DRMC and contemporary URCSA (Strauss 2005:572). Bam (in Botha \& Naude 1998:34-37) concurred, however, that it is a confession on the same level as the other confessions of the church. The Confession is ultimately the personification of liberation from injustice, separation and inferiority and the embodiment of its rich ecclesial and confessional identity. The shift in the Confession's narrative plot during 1982/1986 constituted it as a pedagogical therapeutic and transformative agent. ${ }^{6}$

\subsubsection{The development of externalizing conversations}

Externalising conversations focus on different aspects such as psychosocial, cultural, economicpolitical and theological challenges between people, diverse cultures and social practices as well as complex ideological, philosophical and metaphorical problems (Morgan 2000:20-21). The internalization of communities' problems (apartheid and its theological justification) impact negatively on their philosophical disposition (their attitudes, values, character, believes) (De Beer \& Van Niekerk 2009:50-52). An untransformable DRC have become a stuck and maintenance institution with a silo mentality and culture (De Beer \& Van Niekerk 2009:57; Strauss 2005). The aforementioned dynamics could lead to a cycle of pathological problems without alternative outcomes (White 2007:9, 24-25). However, the Confession's poststructuralist theological context

\footnotetext{
5 People should name their own problems, and not the therapist (Morgan 2000:20).

6 The use of historical and contemporary symbols and art like films could be applied to address "unpleasant, serious, chronic and intractable problems in their social consequences ... (White 2007:23-24). Especially through deconstructive listening by accepting and understanding people's narratives without "reifying or intensifying the powerless, painful, and pathological aspects of those stories" (Freedman \& Combs 1996:46).
} 
and inclusive denominational culture (shared by the SACC, USA Presbyterian Church, Germany, The Netherlands, broader society, etcetera) have proved to shape its new found theological conviction (Koopman 2008:162). This socially and culturally influenced church developed its own self understanding, habit of thought and faith and moral practices. URCSA have a natural tendency that instructs its self understanding, due to the mere habit of thought of her moral, cultural and theological heritage (Koopman 2008:162; Hartney 2011; cf. Morgan 2000:9; White 2007:25). The Confession was and remains as such a hermeneutical practice embodying core truths of Scripture (Hartney 2011:103). McLaren (2001:151) refers elsewhere to "the story of God's work in the human community".

Externalising conversations are counter-practices against the objectification of people/ communities' identities (Koopman 2008). The notions of inferiority, disorder, dysfunctionality, incompetency or inadequacy are challenged (cf. White 2007:26). The Confession as an externalising conversation acted as a counter practice in distinguishing the DRMC/URCSA from the DRC and the former oppressive National Party regime. De Beer and Van Niekerk (2009:56) hold that it exposed the DRC's integrity crisis and its crisis for missionary relevance. It decentred the DRMC/URCSA from pathological inferior philosophies and opened up new possibilities to redress the theological justification of apartheid and its psychosocial effects (De Beer \& Van Niekerk 2009; 56-57; Koopman 2008:162; cf. White 2007:26; Freedman \& Combs 1996:56):

This language partnership provided [the Confession of Belhar] with the necessary

scaffolding to cross pathological [political and theological] zones to new life possibilities

(White, 2007:263) ... and created a new reality of meaning (Freedman \& Combs 1996:29).

The deconstruction of oppressive and inferior philosophies is the ultimate objective of externalizing conversations (White 2007:27; Morgan 2000:24):

... our deepest convictions in the words of the Belhar Confession ... helped us to resist apartheid with resilience and hope, and that eventually helped us to overcome this evil system (Koopman 2008:162).

The intention is "not so much problem-solving or direct power struggles", but rather actions of "cool engagement" in expressing anonymous [oppressive] previous life [pre- and post-1994] experiences (White 2007:27-29). Communities' sense of vulnerability in existential life problems and stressful circumstances decrease as a result (White 2007:29). The DRMC was empowered/ liberated through the Confession and accepted responsibility for being socio-politically conscious in deconstructing the DRC's discriminatory theology, antisocial ideas, beliefs and actions (Koopman 2008:160-164; cf. Morgan 2000:45).

The Confession re-authored the DRMC's sense of being part of a preferred democratic community and multiracial church. The notion of the Confession that God is in a special way on the side of the sufferer, poor and oppressed (Botha \& Naude 1998:4-5) opened public space for a concrete understanding (a catharsis moment) of her life and identity in constructing new stories (White 2007:31; Freedman \& Combs 1996:56ff). Metaphors are basically not intended as battle and contest metaphors to defeat or vanquish injustice, separation and inferiority (White 2007:30-31). The DRC's constant tendency in problem totalising (negative perception) of the Confession, should be challenged (De Beer \& Van Niekerk 2009; Strauss 2005). Relentless theological discourse by the DRC obscure[d] the context of apartheid, injustice and its effect during the 1980's until today (De Beer \& Van Niekerk 2009:61). It attempts to invalidate the DRMC/URCSA's identity, humanity and culture (Koopman 2008:161; White 2007:35). ${ }^{7}$ Strauss' (2005:572-573) remark, that the Confession occupies itself with peripheral issues and not with central faith issues, totalised the DRMC/URCSA's pre- and post 1994 authentic experience into

7 "This totalizing of the problem is founded upon the dualistic, either/or habits of thought that have been quite pervasive in Western culture ...” (White 2007:35). 
moral and peripheral issues (Hartney 2011). Metaphors of battle and contest and a totalizing of the Confession as a problem are only appropriate for some people in the DRC - those who are fighting for their White supremacy survival since and during 1982, 1986, 1994 and beyond (De Beer \& Van Niekerk 2009:60-63; Strauss 2005, cf. White 2007:35).

Externalizing conversations were used in the revisioning and redeveloping of the DRMC's strengths and resources (Koopman 2008; Van Rooi 2010; cf. White 2007:38). Koopman's (2008:166) post-1994 observation embodies an externalising conversation in the DRMC and URCSA:

In the quest for the restoration of human dignity, i.e. in the quest to build an ethos of social solidarity and social cohesion, embrace and participation, compassion and justice we drink from the wells of the Christian tradition. ... The threefold office of Christ might enrich our theological contents ...

It could help the DRC to begin revisioning her life and to gain renewed strength in herself - to "tap" into her traditional neighbourhood and friends as a therapeutic and narrative pedagogical resource (De Beer \& Van Niekerk 2009:58,61). The different, absent but implicit metaphors used by both Koopman (2008:166): restoration of human dignity; and Strauss (2005:574575): the confession's "afgeleide gesag" [assumed authority]; illustrate the therapeutic and hegemonic power of externalization conversations, respectively. Strauss' (2005:575) notion of the confession's "afgeleide gesag" [assumed authority] resonates with hegemonic dominance and power which led numerous times to power harassment (De Beer \& Van Niekerk 2009:53; Van Dijk 1993:255). Bam (in Botha \& Naude 1998:34-37) redressed White hegemony and spearheaded the DRMC's 1982 status confessionis in witnessing:

I came to a place where I understand apartheid regulations as a contradiction to the Gospel of Jesus Christ. I experience this faith clash so sharply that it forces me to witness and reject the false doctrine that threatens me. I find myself in a situation where I either witness confrontationally against the powers which threaten to neutralise and disempower my faith confession, or am silenced and crumble to nothingness. When I find myself in a status confessionis then the word which speaks in this situation should have the status and character of a confession (own translation).

The appropriation of Bam's external conversation for the URCSA in the aforementioned and following paragraphs is crucial to inculcate the values of the Confession and in redressing complex contemporary issues.

\subsection{Position map: four categories of inquiry}

The "statement of position" map applied to a narrative pedagogy context, facilitates externalizing conversations, distinguished by four principal categories of inquiry (White 2007:38-39). The "statement of position" map functions as a narrative pedagogical therapeutic inquiry guide; where people present problem-dominated life issues and or individual/relational pathological identities (White 2007:39). Narrative pedagogy takes on a decentred position in helping people to name their own problems and to voice their concerns in their positions to their problems (White 2007:39).

\subsubsection{Naming the problem}

The first task of narrative pedagogical therapy is to assist URCSA as well as DRC members in the naming of their current existential problems. Their existential and psychosocial problems are richly characterised through their experience-distant (global) problems by rendering it experience-near (particular) problems (White 2007:40). URCSA's unique knowledge, capabilities and skills are central in readdressing existential problems (De Beer \& Van Niekerk 2009:62- 
63; White 2007:43). Pedagogical therapy, in this instance, could use language in a particular manner to foster decentred specific problem-identity conversations (Morgan 2000:18). The Confession as a missional witness (De Beer \& Van Niekerk 2009), is not "'n liriese ontboeseming of emosionele ontlading nie" - it is a daring act of conflict (Bam in Botha \& Naude 1998:37). The Confession became the DRMC/URCSA's liberating moment, and renamed and transformed its own pathological position into one of unintentional care, compassion and healing for the DRC and broader public (Koopman 2008:163-164; De Beer \& Van Niekerk 2009:62-63).

\subsubsection{Mapping the effects of the problem}

It was and remains important to address the effects or influence apartheid had and continues to have on people's lives (De Beer \& Van Niekerk 2009:52-53; Koopman 2008:164; Van Rooi 2010:176-177). Narrative pedagogy should appropriate the impact of the dominant [apartheid] story in people's lives (cf. Morgan 2000:39-40; White 2007:43). The tactics/methods and consequences of apartheid, discrimination and unjust conditions should be addressed. For example, how has the Confession affected how the DRMC functioned during the 1980's and thereafter? (Botha \& Naude 1998; Koopman 2008:159-162; cf. Morgan 2000:40). The DRMC/ URCSA critiqued the DRC's hegemonic tactics of influencing discourse and meaning regarding the Confession (Hartney 2011:94,103; Koopman 2008; cf. Morgan 2000:33-38,40). The Confession constituted an alternative story. The manner in which the DRMC/URCSA coped in the face of injustice and oppression was due to her psycho-social and spiritual competence (Koopman 2008:159-162; cf. Morgan 2000:41). The transition from internalizing conversations in the DRMC/URCSA became evident in its public missional witness (Botha \& Naude 1998:3437; De Beer \& Van Niekerk 2009:56-57; cf. White 2007:43). Externalising conversations shift pathological philosophies to enable decentred identity formation and transformation (White 2007:44).

\subsubsection{The effects of oppressive/unjust practices}

Apartheid and its effects on contemporary people's lives should be redressed (Koopman 2008:166). Appreciative enquiry should be applied in guiding people to consider and articulate their opinions in this regard (White 2007:44; Morgan 2000:42). Therapeutic narrative pedagogy should articulate the complexities of peoples' positions on the effects of apartheid (White 2007:46; Morgan 2000:42). The Truth and Reconciliation Commission (TRC) started this process, but left a narrative therapeutic vacuum after it was dissolved (http://www.justice.gov.za/ $\mathrm{trc} /$ ). The DRC's prophetic and pastoral voice in terms of the "what, why and how" questions of apartheid, would have helped to transform its identity (Koopman 2008:166; cf. Morgan 2000:42). However, the DRC's attitude (Strauss 2005) towards the Confession inspired the URCSA's missional witness, informed and emphasised its meaning in life (De Beer \& Van Niekerk 2009:58).

The "why" question motivated or justified how people evaluate the effects of apartheid in their lives (cf. White 2007:48; Morgan 2000:43). It is not associated with moral judgement and values (Hartney 2011:103). It gives people a voice and develops their framework (intentions, values, skills, competences, preferences and praxes) for living (Koopman 2008:165; White 2007:49; Morgan 2000:43). It also helps to develop positive identity and preferences for living. People can decentre themselves from [apartheid-] saturated stories to aspire for rich story development and alternative stories (White 2007:49,51; Morgan 2000:43). The Confession succeeded in decentring itself from the DRC's justification of apartheid (De Beer \& Van Niekerk 2009:51-52). 


\subsubsection{Thickening the alternative stories}

Towards a renewed role of the Confession in the URCSA - the introduction of narrative pedagogy in churches, schools and communities could support communities to stay connected to their new and preferred stories (cf. Van Rooi 2010). Thickening and enriching the alternative stories of unity, reconciliation and justice may involve witnessing in the articulation of new stories (De Beer \& Van Niekerk 2009; Koopman 2008:164ff; Morgan 2000:74-75). De Beer \& Van Niekerk (2009:56ff) interprets the Confession in terms of its missional value/witness an highlight it as an alternative narrative. The Confession however cannot be reconfigured through creative linguistics to argue for an alternative confessional identity in advancing church unity. Especially for those DRC members who continues to resist the Confession's original intention and full implications. The Confession is in nature subversive and prophetic (Bam in Botha \& Naude 1998:35). Re-authoring conversations, re-membering conversations and the unique outcomes methodology will henceforth be applied in order to thicken the pedagogical therapeutic value of the Confession as the URCSA's alternative narrative (Koopman 2008:159-162). The aforementioned narrative frameworks are crucial in fostering authentic historical memory and pedagogical therapeutic space for the younger and future generation leaders.

\subsection{Re-authoring conversations}

Narrative pedagogy should explore unique outcomes for pathological socio-economic, political and theological conditions through historical analysis and hermeneutics (Hartney 2011). New plots and alternative stories could emerge - described with new meaning and linked to past events (De Beer \& Van Niekerk 2009:52,62-63). In the retelling and reliving of stories lies the rediscovery of a story which relates to a new situation (Freedman \& Combs 1992:33). People can shift from oppressive-saturated living to a reconnection with communal preferences, hopes, dreams and ideas (Morgan 2000:59):

These themes often reflect loss, failure, incompetence, hopelessness, or futility. Along with this, people routinely refer to the figures or protagonists that feature in the story, and they share with therapists their conclusions both about the identity of these figures or protagonists and about their motives, intentions, and personal characteristics (White 2007:61).

The embodiment of White's (2007) notion of communal praxis was demonstrated in the TRC process. The TRC initiated an unprecedented project of reconciliation and social justice, but failed to sustain its work. Current socio-political and moral conditions in the country require similar projects to facilitate reconciliation and social justice (Dames 2009). The URCSA should renew its own confessional vocation to redress contemporary challenges. This re-authored DRMC/URCSA situation (1982/1986) was a defining moment in search of reconciliation, restitution and justice from both the DRC and apartheid government. Such re-authoring conversations are crucial for traumatised and fragmented societies due to ongoing violence, corruption, poverty, xenophobia and renewed instances of discrimination and prejudice.

Re-authoring conversations are defined by landscape of action and landscape of identity questions (White 2007:78,81-82). Events, action and beliefs which do not fit with the [URCSA's] dominant story are explored (Morgan 2000:60; cf. Strauss 2005). Landscape of action and landscape of identity create a context or open space in which South Africans can give meaning to and assimilate overlooked, but significant events, of their lives into a coherent storyline (White 2007:83). The landscape of action develops over time through a sequence of experiences, events and contexts by creating a specific plot. The landscape of identity seeks to understand the knowledge, thoughts, or feelings, or absent knowledge, thoughts or feelings in people's actions (White 2007:78). De Beer and Van Niekerk's (2009:63) notion of the missionary value of 
the Confession, if authentically appropriated, is an example of its pedagogical and therapeutic potential. The potential outcome is God's preferred future - people become engaged with many of the lost experiences and events in their own living contexts (Keifert 2006; White 2007:81). The refinement and development of future conversations become critical (White 2007:81). People's lives become multi-storeyed as their landscape of identity is identified and thickened (White 2007:81). We can distinguish between interactive plots in the narratives of Koopman (2008) and Strauss (2005):

The most significant landscape of action and of identity played itself out in [Koopman's 2008 narrative], after decades of suffering of injustice and oppression posses an open externalised question to [his fellow theologian colleague, Strauss 2005]. His question signalled a catharsis moment in the whole story, but in the views of his fellow colleague, one could sense the perplexity of being confronted with reality and personal agency and responsible action (White 2007:266).

Koopman's narrative is the catalyst for pedagogic therapeutic healing and reconciliation between the URCSA and DRC.

\subsection{Re-membering conversations}

Re-membering conversations anchor on an understanding that identity is grounded in communities (White 2007:129; Morgan 2000:77). Isolation and disconnection from meaningful relationships are generally experienced by postmodern people faced with problems. Dominant apartheid stories minimised Black and "Coloured communities" collective histories. Remembering conversations deconstruct these dominant apartheid stories. It "powerfully incorporates and elevates significant people's contribution in the lives of those consulting the [narrative pedagogy] therapist" (Morgan 2000:77). The Confession's voice was formative with regard to the construction of DRMC/URCSA's own new identity (Koopman 2008; De Beer \& Van Niekerk 2009; cf. White 2007:129; Morgan 2000:83ff).

Re-membering conversations provide URCSA and the DRC with an opportunity to critique the authentic membership of the church. Suffice it to state that silent voices gain authority in claiming its community identity and in challenging other hegemonic [unjust and oppressive DRC] voices (White 2007:129). Historical events, experiences and contexts which stand outside the influence of apartheid are sought through the landscape of action and landscape of identity (Morgan 2000:78). In so doing, communities can reengage with their history or revision their relationships with significant Others. New contemporary identities and projected futures are reconstructed (De Beer \& Van Niekerk 2009; White 2007:136).

The Confession became a therapeutic narrative pedagogical agent and an outside audience for the Others' [DRC, society] stories (De Beer \& Van Niekerk 2009; cf. White 2007: 208ff).

\subsection{Conversations that highlight unique outcomes}

It could be contended that many DRMC/URCSA members still live consciously/unconsciously with the scars of unconscious hegemonic stories of suffering (Koopman 2008:159-162; Van Rooi 2010). Hidden or unconscious stories could be significant and are defined as unique outcomes or exceptions in favourable circumstances. Unique outcomes do not necessarily fit with the dominant story. It may be an action, statement, thought, belief, ability and commitment (Morgan 2000:52). The identification thereof engenders alternative storylines. Many neglected unconscious, lived experiences of the URCSA became public through the Confession (Koopman 2008:159-162; cf. White 2007:219). Unique outcomes function[ed] in the past, present and future - free from dominated apartheid-saturated stories (De Beer \& Van Niekerk 2009:52; Naude \& Botha 1998; Morgan 2000:54). People are liberated or healed to voice their own 
intentions, values (White 2007:220), alternative stories and rich descriptions for their lives and social relationships (Morgan 2000:55). These facets become motivators for transformative action in the DRMC/URCSA (De Beer \& Van Niekerk 2009:51; White, 2007:220). Unique outcomes are related to events that are linked to both the dominant and invisible storylines of people - towards collective and preferred values (De Beer \& Van Niekerk 2009:52-53; White 2007:232233; Morgan 2000:55). Alternative storylines are generated and transcends the dominant and oppressive-saturated storylines (White 2007:233-243). A new DRMC/URCSA community identity resulted with reconstructed social-meaning (De Beer \& Van Niekerk 2009:51).

\section{DRINKING FROM OUR OWN WELLS}

The shift from structuralism to post-structuralism has a direct theological implication. Theology itself has made paradigm shifts which have impacted society on multiple levels. Liberation theology, black theology and feminist theology changed the way people, society and institutions should be perceived, approached and valued (Boesak 1975; 1977; Beyers Naudé in Berkhof, H. et al. 1985; Cone 1975 \& Wimberley 1979). This shift represents a departure from traditional held assumptions and philosophies about life, people, the church, etcetera. Key to such a paradigm shift is the fact that the church or theology does not hold all the truth and authority in people's lives. The existential context of any society and its people should duly be recognised and respected in therapeutic narrative pedagogy (De Beer \& Van Niekerk 2009:52-53; Bonino in Berkhof et al. 1985:139-155; Cone 1975:39-80; Wimberley 1979:20).

\section{CONCLUSION}

The missional nature of Church unity should not substitute the authentic witness of the Confession and its subversive enactment against hidden apartheid and paternalistic theology ideologies and practices. Such is the potential for narrative therapy, that it unlocks the hidden treasures that lie dormant in the rich lives of people who are blindfolded by modern as well as postmodern - hegemonic, structuralist religious beliefs. The Confession of Belhar holds and exposes such hidden, albeit public practical theology treasures to engender pedagogic narrative therapy for divisive, broken and traumatised communities.

\section{BIBLIOGRAPHY}

Boesak, A. 1975. Om het Zwart te Zeggen. Een Bundel Opstellen over Centrale Thema's in de Zwarte Theologie. Kampen: J.H. Kok.

Boesak, A. 1977. Afskeid van de Onschuld. Een Sociaal-ethische Studie over Zwarte Theologie en Zwarte Macht. Kampen: J.H. Kok.

Berkhof, H. et al. 1985. Met de Moed der Hoop. Opstellen aangeboden aan Dr. C.F. Beyers Naudé. Ten Have: Baarn.

Botha, J. \& Naudé, P. 1998. Op pad met Belhar. Goeie nuus vir gister, vandag en môre. Goodwood: Van Schaik.

Cone, J.H. 1975. God of the Oppressed. New York: The Seabury Press.

Clough, P. 2002. Narratives and Fictions in Educational Research. Doing qualitative research in educational settings. Philadelphia: Open University Press.

Dames, GE. 2009. Ethical Leadership for a Morally Transformed Society. (ed.) Stellenbosch: SunMedia

De Beer, JM \& Van Niekerk, AS. 2009. Die Missionêre Waarde van Belhar en die NG Kerk-familie se Herenigingsgesprek. The Missional Value of Belhar and the DRC-family's Reunification Talks. NGTT 50(1\&2):50-65.

Freedman, J. \& Combs, G. 1996. Narrative Therapy. The Social Construction of Preferred Realities. New 
York: W.W. Norton \& Company.

Goodson, IF, Biesta, GJJ, Tedder, M \& Adair, N. 2010. Narrative Learning. London: Routledge.

Hartney, JNM. 2011. Eksegeties-teologiese ondersteuning van die Belydenis van Belhar. Exegetic-

theological analysis of some Biblical concepts in the Confession of Belhar. NGTT 52(1\&2):94-104.

Keifert, P. 2006. We are Here Now. A New Missional Era. A Missional Journey of Spiritual Discovery. Idaho: Allelon.

Koopman, N. 2008. On Violence, the Belhar Confession and Human Dignity. NGTT 49(3\&4):159-166.

Kotzé, E (ed.) 2000. A Chorus of Voices. Weaving Life's Narratives in Therapy and Training. Pretoria: Ethics Alive.

Landman, C. 2009. Doing narrative counselling in the context of township spiritualities. Retrieved at http:// www.unisa.ac.za/library on 21 July 2011.

Louw, D.J. 2008. Cura Vitae. Illness and the Healing of Life. Wellington: Lux Verbi.

McLaren, B.D. 2001. A New Kind of Christian. A Tale of Two Friends on a Spiritual Journey. San Francisco: Jossey-Bass.

Morgan, A. 2000. What is Narrative Therapy? An Easy-to-read Introduction. Adelaide: Dulwich Centre Publications.

Morkel, E. 2008. Post-Modern Epistomology. M.Th. Pastoral Care and Counselling Workshop Notes, 2008. Stellenbosch University.

Murphy, F.A. 2007. God is not a Story. University of Aberdeen. Retrieved at www.oxfordscholarship.com on 30 August 2011.

Novelli, M. 2008. Shaped by the Story: Helping Students Encounter God in a New Way. Zondervan: Grand Rapids.

Ploeger, A.K. 1995. Inleiding in de Godsdienstpedagogiek. Kampen:Kok.

Strauss, P.J. 2005. Belydenis, Kerkverband en Belhar (Confession, Denomination and Belhar). NGTT 46(3\&4):560-575.

Taylor, S. 2005. The Out of Bounds Church? Learning to create a community of faith in a culture of change. Zondervan: Grand Rapids.

Thomas, L. 2002. Poststructuralism and therapy - what's it all about? The International Journal of Narrative Therapy and Community Work. 2002(2):85-89. www.dulwichcentre.com.au.

Van Dijk, T. A. (1993) Principles of critical discourse analysis. Discourse \& Society. (London, Newbury Park and New Delhi) 4(2) pp. 249-283.

Van Rooi, L. 2010. Identity, boundaries and the Eucharist. In search of the unity, catholicity and apostolicity of the Church from the fringes of the Kalahari Desert. NGTT 51(1\&2): 176-185.

White, M. 2007. Maps of Narrative Practice. New York: W.W. Norton \& Company Inc.

Winslade, J. \& Monk, G. 1998. Narrative Therapy in a Nutshell. [Notes taken from: Narrative Counselling in Schools: Powerful and Brief] California: Corwin Press.

Wimberley, E.P. 1979. Pastoral Care in the Black Church. Nashville: Abington.

\section{Electronic Sources}

http://www.timeslive.co.za/sundaytimes/?gclid=CKL-ys6r-aoCFdAJtAodKBIIlg. Retrieved on

31 August 2011. http://www.news24.com/Galleries/Image/Images/MyNews24/Malema\%20

Luthuli\%20hearing. Retrieved on 31 August 2011.

http//www.justice.gov.za/trc. Retrieved on 31 August 2011.

\section{KEY WORDS}

Practical theology

The Confession of Belhar

Pedagogical-therapeutic narrative maps

Psychosocial dysfunctionality in church and society

Poststructuralist paradigms 


\section{TREFWOORDE}

Praktiese teologie

Die Belydenis van Belhar

Pedagogies-terapeutiese narratiewe aanwysers

Psigososiale disfunksionaliteit in kerk en samelewing

Post-strukturele paradigmas

Contact Details

P.O. Box 392

Unisa

0003

damesge@unisa.ac.za 